69. Political Philosophy (23 $3^{\text {rd }}$ World Congress of Philosophy, Athens 4-10 August 2013)

\title{
Title: Can perspective relativism be defended in the face of the evident evil that terrorists bring about?
}

\begin{abstract}
In this paper, it is argued that terrorism undermines the justification of perspective relativism. The cliché, "one person's terrorist is another person's freedom fighter," is offered as an example of perspective relativism. Perspective relativists argue that moral principles and judgments have no universal moral import. Those who defend the cliché expression presuppose that the evaluation of terrorism is necessarily perspectival. For them, there are no morally objective differences, e.g., between deliberately killing combatants and deliberately killing innocent noncombatants. Yet there are morally objective differences between these two acts. While the first act might be justified, the second act is considered murder. Hence, the evaluation of terrorism is not necessarily perspectival. Therefore, in the face of the evil that terrorists bring about, it is argued that perspective relativists have a substantive burden of proof to show that there are no transcultural moral values.
\end{abstract}

Key words: Terrorism, Perspectivism, Relativism

Abstract word count: 142

Paper word count: 1751

$\begin{array}{ll}\text { Author: } & \text { Vicente Medina } \\ \text { Title: } & \text { Associate Professor of Philosophy } \\ \text { Institution: } & \text { Seton Hall University } \\ \text { Department: } & \text { Philosophy } \\ \text { Address: } & \text { 400 South Orange Ave. } \\ & \begin{array}{l}\text { South Orange, NJ 07079 USA } \\ \text { E-mail: }\end{array}\end{array}$


In this paper, I am assuming that terrorism can be reasonably defined as the use of violence by individuals or groups who deliberately inflict substantive harm on combatants and/or innocent noncombatants alike, including occasionally killing the latter, in trying to achieve political goals. Hence, terrorism can be viewed as equivalent to murder. ${ }^{1}$ Since murder is necessarily wrong, it follows that terrorism is necessarily wrong. I do not, however, intend to defend the above-mentioned definition. I argue that in the face of the evident evil that terrorists bring about by deliberately harming people, including killing innocent noncombatants, the practice of terrorism undermines the justification of perspective relativism.

Perspective relativism is a widely held view, especially regarding controversial issues, such as terrorism. A good illustration of this view is shown by the cliché, "one person's terrorist is another person's freedom fighter." Apologists of terrorism may defend this trite expression based on nihilist or moral relativist grounds. By nihilism I mean the hypothesis that there are no values but only individual preferences. By moral relativism, I mean the hypothesis that moral principles and judgments have no universal moral import. Hence, no moral principles and judgments can be transculturally justified.

By perspective relativism I mean the hypothesis that moral principles and judgments are necessarily depending on an individual's or a people's point of view. For perspective relativists, value judgments have no objective universal moral import. Hence, for them, value judgments are neither right nor wrong for everyone. They may

\footnotetext{
${ }^{1}$ Michael Walzer, Just and Unjust Wars: A Moral Argument with Historical Illustrations, $2^{\text {nd }}$ ed. (New York: Basic Books, 1992), p. 197.
} 
adopt one of the following three different points of view: an individualist, and social or a cultural point of view.

The above-mentioned cliché is ambiguous. So a person who supports it could offer at least two plausible interpretations. One based on the relativity of empirical observations, i.e., descriptive relativism, and the other one based on the relativity of moral evaluations, i.e., moral relativism. Descriptive relativists maintain that based on empirical observations of different people in different societies or cultures there seems to be no universally recognized moral values.

Rather than holding a hypothesis based on empirical observations about how people actually harbor opposite moral beliefs, people who embraces the already mentioned cliché may be offering a hypothesis based on a normative or moral claim. That is, the same judgment that is conceived of as right in one society or culture is conceived of as wrong in another society or culture. As a result, they believe that there is no Archimedean point of view to establish whether a judgment is right or wrong. This view is known as moral relativism.

Those who adopt an individualist perspectivist view can be conceived of as nihilists. ${ }^{2}$ For nihilists, there are no transcendent moral values. So, for them, no significant moral difference exists between, e.g., the deliberate killing of innocent noncombatants, which is considered murder by civilized people, and killing in selfdefense. For nihilists, arguing about morality is just inane. For them, to describe an action as right is simply to have a pro-attitude for it. By contrast, to describe an action as wrong is to have a con-attitude against it.

\footnotetext{
${ }^{2}$ See, e.g., Frederick Nietzsche, The Will to Power, A New Translation by Walter Kaufmann and R. J. Hollingdale (New York: Random House, 1967), aphorism 481, p. 267. See also, Frederick Nietzsche, Thus Spake Zarathustra in The Philosophy of Nietzsche, (New York: The Modern Library, 1954), ch. 15.
} 
Ivan Fyodorovitch's argument in Fyodor Dostoyevsky's classic novel, The Brothers Karamazov, is a good example of nihilism. Ivan contends that without believing in a transcendent being, such as God, who could ultimately establish right and wrong everything would be morally and legally permissible. He states, "if you were to destroy in mankind the belief in immortality ... nothing then would be immoral, everything would be lawful, even cannibalism. ${ }^{3}$ According to Ivan's pro-nihilistic attitude, even terrorism could be morally and legally permissible.

Fair-minded people, however, are likely to find nihilism appalling. To argue, as nihilists do, that there are no significant moral differences between, e.g., the life of a saint and the life of an assassin, the life of a criminal sadist and the life of an innocent child is to commit oneself to a futilitarian view of the world.

If we were to challenge the nihilists about why they have a given pro or conattitude about terrorism, they could provide the following two plausible answers. That is how they actually feel, in which case they would be begging the question. Or they could claim that they feel that way because people generally feel like them. So they would rather be offering an empirical explanation about other people's feelings. The burden of proof, however, would be on their shoulders to demonstrate that reasonable people actually feel that way.

Regardless of which answer nihilists provide, they deny that there are moral facts that we can appeal to in trying to settle our moral disagreements. Yet apologists of terrorism who embrace the cliché, "one person's terrorist is another person's freedom fighter," need not be nihilists. Genuine nihilists are indifferent to how other people view

\footnotetext{
${ }^{3}$ Fyodor Dostoyevsky, The Brothers Karamazov, cited in Peter Singer and Renata Singer (eds.), The Moral of the Story: An Anthology of Ethics Through Literature (Malden, MA: Blackwell, 2005), pp. 436437.
} 
the use of political violence, including terrorism. Like apologists of terrorism who support them, terrorists generally have a political agenda.

Unlike nihilists, those who adopt a social or cultural perspectivist view argue that value judgments can only be defended as right or wrong within a society or a culture where they have been adopted. The justification of value judgments depends on a given set of moral principles, rules, and standards accepted by the people living in a given society or culture.

Those who adopt the cliché, "one person's terrorist is another person's freedom fighter" could be defending any of the above-mentioned versions of perspectivism. For example, for nihilists, the same group of people might be labeled by some as freedom fighters and as terrorists by others. But people's pro-attitudes or con-attitudes can change at any moment if their beliefs change. Hence, the nihilists' point of view is rather fluid and ad hoc.

Social or cultural perspectivists seem to fare no better than nihilists do. While they need not do so, when challenged, they may revert to descriptive relativism. But descriptive relativism only proves the obvious, i.e., that sometimes individuals harbor opposite moral judgments regarding the same contestable issue based on a different set of beliefs. The point, however, is whether their beliefs are justified.

When making judgments, especially moral judgments, one can accept them as well-founded and, hence, as right based on epistemically and/or morally justified beliefs. Or one can reject them as ill-founded, and, hence, as wrong based on epistemically and/or morally unjustified beliefs. For example, the following value judgment could be reasonably and objectively defended as well-founded based on epistemically and/or 
morally justified beliefs: "Mother Teresa's way of life is better than Osama bin Laden's way of life."

I have reason to believe the value judgment or evaluation that "Mother Teresa's way of life is better than Osama bin Laden's way of life" is right or true. That is, any reasonable person has a right to accept the judgment unless it is shown to be wrong or false. Roughly speaking, a reasonable person is an intellectually fit person who is intelligent, accept the value of doxastic coherence, and has a properly function belief system, i.e., a system that generally is conducive to truth.

One may challenge, however, that the term 'better than' in the above-mentioned evaluation is contestable based on its relative variance. Yet a compelling case can be made that the term 'better than' means "morally better than" in a transcultural sense. By the expression 'morally better than' I mean "improving rather than harming innocent people's lives."

Mother Teresa of Calcutta, who won the Nobel Peace Prize in 1979, dedicated her life to improving the life of the needy, even putting herself in harm's way in doing so without intending to harm anyone. Unlike Mother Teresa, bin Laden dedicated his life to a campaign trying to establish a new global caliphate under sharia law by indiscriminately targeting combatants and innocent noncombatants alike. In doing so, he brought mayhem not only to the so-called infidels, but also to his own people. He even violated the spirit of the Quran, which forbids the intentional killing of the innocent. Therefore, it would be conceptually and practically incoherent to defend the view that bin Laden helped to improve innocent people's lives in any meaningful sense. 
Nihilists, however, are likely to deny that the above evaluation has any moral import. That is, that it can be right or wrong independently of people's pro or conattitudes. For nihilists the predicate "right" simply means that some people have a proattitude in favor of Mother Theresa's way of life, and the predicate "wrong" simply means that some people have a con-attitude against bin Laden's way of life, or vice versa.

Like nihilists, social or cultural perspectivists argue that moral judgments depend on a people's preferences and attitudes. Unlike nihilists, however, they do not reduce the moral import of value judgments to a person's pro or con-attitudes, but rather to the preferences and attitudes reflected by the people living in a society or a culture. So, for them, the predicate "right" could simply mean that people living in a given society or a given culture have a pro-attitude in favor of Mother Theresa's way of life. By contrast, the predicate "wrong" could simply mean that people living in a different society or culture might have a con-attitude against Mother Teresa's way of life. Hence, the same judgment that is conceived of as right in one society or culture is conceived of as wrong in a different society or culture.

Perspective relativism, however, seems arbitrary and offensive to fair-minded people who defend a minimal sense of transcultural human decency. There are certain acts that are beyond the pale, such as the deliberate targeting of innocent noncombatants, the torturing of people (especially innocent noncombatants), the practice of genocide and ethnic cleansing, and the raping of individuals, especially as a matter of war policy. In the face of the evident evil that terrorists bring about, the burden 
of proof is on perspective relativists to provide convincing arguments to demonstrate that the predicates "right" and "wrong" have no transcultural independent meaning. 